Article

\title{
Relational Ethics: Volunteering and the Responsibilities of the Good Muslim
}

\author{
Merve Reyhan Kayikci \\ Semitic Studies, University of Granada, 18071 Granada, Spain; mervereyhan.kayikci@kuleuven.be
}

Received: 14 January 2019; Accepted: 25 February 2019; Published: 1 March 2019

\begin{abstract}
This article explores the ways in which female Belgian Muslim volunteers experience responsibility. It argues that responsibility consists of multiple dynamics for the volunteers, for example, the duties that are embedded in the Islamic tradition and the duties that arise from being a good citizen in a liberal/secular context. While these are often emphasized as being contentious binaries-especially for Muslims living in the West-this paper suggests that volunteering allows the Muslim women to bring these worlds together. The ways in which volunteering enables this is by introducing a relational reading of ethics and ethical self-formation. Relationality is highly significant for the female Muslim volunteer. It signifies being in touch with both (non-liberal) Islamic ethics and liberal public norms, even when pursuing a pious lifestyle. Hence, the article explores the ways in which responsibility is actualized in this framework. Finally, the last section interrogates how this idea of responsibility and relationality re-articulates binaries of the good-Muslim and the bad-Muslim.
\end{abstract}

Keywords: responsibility; relationality; maslaha; volunteering

"A good Muslim cannot expect to just pray five times a day and expect God's repentance". These are the words of my interlocutors, the Belgian Muslim volunteers. The women whom I followed for nearly four years in their volunteering activities, and from whom I learned that a good Muslim is a Muslim who reaches out to society. They are women who have conveyed to me time and again that ibada (personal worship) does not mean much if a person is in desire for God's consent if that same person does not extend their pious intentions to include the well-being of other people. According to my interlocutors, the female Muslim Belgian volunteers, the two entities-ibada and volunteering-are complimentary, in the sense that a good Muslim is one that is diligent in their ibada, and committed to their responsibilities with regard to society. Hence, this is what they invest in everyday as their volunteer from their associations.

My time with the female volunteers has surfaced the complex, multiple, and often interconnected layers of the idea of social responsibility. This is quite an ambiguous term that can literally refer to multiple forms of subjectivation. In the liberal state, along with citizenship comes a set of rights and entitlements, but it also requires certain obligations to be fulfilled by the citizen (Janoski 1998). Members of a nation are expected to share similar values; they are expected to adhere to social norms, to respect the rights of others, and to contribute to their nation in different ways (Etzioni 2011). Ideas of responsibility can vary greatly within each nation. In the case of my interlocutors, it is also a phenomenon deeply embedded in the Islamic tradition.

In the current literature there is a strong position towards individualization and that Muslim self-governance is grounded in liberal interpretations of agency, which includes liberal affects and practices (Fadil 2008). This means that while Muslims persist in identifying with their religion, the ways in which they identify with their religion are profoundly informed by 'de-traditionalization', or 'de-culturalization', of religious knowledge and practice. It is a pursuit of a more 'individualized' and 'personalized' religious trajectory (Cesari 2004). More explicitly, it is suggested that there is 
a search among Muslims, to find 'authentic' Islam that is detached from culture/tradition and offers a correct way of living Islamically (Fadil 2015; Deeb 2006; Schielke 2007; Salvatore 1997). Amir-Moazami and Salvatore (2003) observe that such individualization and pursuit of authentic knowledge does not mean that religious authority is dismantled. They interpret this as a pluralization of authorities and inclusion of a wider audience (i.e., women), a 'search for coherence (within the tradition)' (Asad 2009), and self-reform (Amir-Moazami and Salvatore 2003, p. 53).

My focus in this research is both engaged with this discussion but also attempts to bring a nuanced experience of Muslim self-formation. On one hand the pursuit of being a proper Muslim touches this process of authentication; on the other hand, the ways in which my interlocutors relate to the hermeneutics of religious texts and embody them is somewhat divorced from the individualization model. In this article I unpack the implications of being a community-a community of volunteers - and the consensual adoption of practices and commitments that are articulated within the group. I suggest a strong relational attachment in my interlocutors' pious trajectory, not only attachments to the liberal post-post-Enlightenment values but also to their (volunteering) community goals and visions. Relationality is embedded in two trajectories: First, the relationality between the volunteers and the society they live in (including the institutions that govern society); and second, the relationality between the two moral traditions that are liberalism and Islam.

I argue that my interlocutors' pious trajectory is embedded in how far they are committed to society. On the one hand this commitment is grounded in liberal conceptions of responsibility, on the other hand, it is inspired by non-liberal (Islamic) interpretations of the common good and agency. The volunteers' subject position is fashioned through the conversation of these traditions. In turn, this subject position informs how they reflect on and practice responsibility. Ultimately, I claim that the formation of their Muslim self, which is fashioned according to such deliberations in turn excludes other types of Muslim selves as non-relational and thus as 'not-good-Muslim'.

\section{Sketching the Scene}

My interlocutors are volunteers, who are Muslim and mostly of Turkish descent. I interviewed twenty women for this research, although I have interacted with a much higher number of women with consent. The field research took approximately three years, and I took part in many events. Most of the events took place in the associations that are dispersed all over Belgium. Some of the larger associations are based in Brussels, Antwerp and Liege. The associations act as a hub where women come together, but they are also meeting grounds for new members and those who attend the events but are not really members. I also attend the informal meetings of the volunteers. These are named sohbet meetings. These take place once a week, and the women come together in groups of seven to ten in each other's homes. More specifically these get-togethers entail religious discussions, where my interlocutors would read a book, text, or listen to a video sermon. Later, they discuss these sources. This is a type of religious self-education, as no one in the group is really educated in the area of religion but they try to self-teach. It is during these sohbet meetings that I come across the most information, it is the real 'kitchen', where the women share their experiences openly and try to relate to the religious texts through their own experiences and how they understand their self and their society.

It is also during the sohbet that the women design their next events. The religious texts also have an influence on this. The text may mention an issue, like the virtue of education and the women would then take this as an over-arching theme, adapting it to their local context and then designing events according to it. Hence, allowing me to take part in these discussions was a very big indication of trust towards me on their part. Naturally, it was also a sense of great luck on my part. Moreover, my interlocutors' actions were never limited to their private areas-the associations and the sohbet groups. A lot of the events took place in very diverse settings such as the European Parliament, the Flemish, and the Federal Parliaments. They took place in hotel lobbies and sometimes business centers in the EU quarter of Brussels. There were also a couple of events that I attended that took place in the city hall of Antwerp. 
While my interlocutors mostly define themselves as pious Muslims, the associations themselves are not attached to any mosque. They are also not attached to any governmental institution based in Turkey. For my interlocutors it is highly important that they are in Belgium and stay Belgian. That being said, most of our discussions took place in Turkish and I have translated them into English. While the events are structured to be carried out in Dutch, French, or English (depending mostly on the venue), the interpersonal discussions were mostly in Turkish. I can safely say that the multilingual nature of Belgium contributed a lot to this choice, because after all, Turkish is the one common language they can gather around. Finally, I do not mention the names of the associations or the real names of my interlocutors for ethical reasons. While they were comfortable with openness in the beginning of my research, the recent political tension in Turkey ${ }^{1}$ has lead them to adopt a different manner where it would be safer and easier for them to remain anonymous.

\section{Relational Ethics}

In interrogating my interlocutors' relational experiences, I borrow Emmanuel Levinas' idea of relational ethics. What drew my attention to his work in particular is the emphasis Levinas makes on the intricate yet irrevocable relationship between the I and the Other. The self and the other is in a constant and non-negotiable ethical conversation. In Totality and Infinity: An Essay on Exteriority he quotes:

To approach the Other in conversation is to welcome his expression, in which at each instant he overflows the idea a thought would carry away from it. It is therefore to receive from the Other beyond the capacity of the I, which means exactly: to have the idea of infinity. But this also means: to be taught. The relation with the Other, or Conversation, is a non-allergic relation, an ethical relation; but inasmuch as it is welcomed this conversation is a teaching. Teaching is not reducible to maieutics; it comes from the exterior and brings me more than I contain. In its non-violent transitivity the very epiphany of the face is produced. (Levinas 1969, p. 51)

In Levinas' theory, the "face of the other" bears incredible weight in this ethical becoming. Especially in Totality and Infinity (Levinas 1969), he describes when the individual comes in contact with the "face" of the other they also come in contact with their self; a part of their self that is invisible to the subject herself but is a projection of the other's perception of their self (see Levinas 1969). He emphasizes the significance of alterity in relationships, adding: "my ethical relation of love for the other stems from the fact that the self cannot survive by itself alone, cannot find meaning within its own being-in-the-world, within the ontology of sameness [ ... ]" (Levinas et al. 1986, p. 24).

Moreover, the face of the other ignites an ethic of responsibility to the $I$; a responsibility whose source is not their own personhood but the mere presence of the other (Levinas 1969). This may come as a bit complicated and even ambiguous, but in order to make it clearer we need to follow thoughts on ethical responsibility in liberal thought. It is exactly the close reading on how this matter is conceptualized in modern thought that brought me closer to Levinas' philosophy, and ultimately a phenomenological reading of my data.

Conceptions of moral or ethical theory are rooted in Enlightenment thinking, placing the individual at the center of society, and developing a thought on ethics that is based on human reason and agency (Venn 2000). Enlightenment humanism pursues the notion that the individual has the ability to govern her/himself, independent from a metaphysical order (see Schneewind 1998; Lindley 1986). Ideas on autonomy relate closely to questions of moral responsibility (Lindley 1986). Responsibility usually figures in terms of 'self-responsibility', reiterating "accountability, duty and

1 On 15 July 2016 a coup attempt took place in Turkey after which the government cracked down on thousands of critiques. During and after this period the political tension has only but slightly simmered down. For more on this matter see (Milan 2016; Abbas and Yigit 2015). 
blame" (Diprose 2008, p. 619; see also Topolski 2015). This conceptualization of responsibility goes back to 20th century philosophy and emphasizes the centrality of the individual's "free will and determinism" in determining their capacity for responsible action. This statement focuses responsibility on the human individual, and supposes that this is a capacity that must be taken seriously.

In terms of individual responsibilities, there are several angles to be considered. First is that individuals can be considered accountable/punishable/blamable/appraisable for their past conduct. Second, individuals have potential responsibilities concerning their duties, as family members, professionals, citizens, etc. Both these strands not only have personal ethical implications, but also legal concerns. This typically categorizes the individual 'liable' for the consequences of their personal judgments. A common thread in these philosophical assumptions seems to be that responsibility begins and ends with the individual. Whether in Kantian rational morality or Aristotle's emphasis on the moral character, modern thought suggests that it is the individual who is accountable for their actions and thoughts. Moreover, it is the individual who discerns responsibility, be it by rational deliberation or virtuous characters.

While there is an implicit understanding that responsibility develops relationally-can there be a sense of responsibility without being responsible to others?- the emphasis on society has only recently become part of the discussion. Especially phenomenologists ensuing Husserl and Heidegger focus on the intersubjective (Letiche 2006, p. 13). My wish here is not to develop on an elaborate philosophical debate, but to draw on some figures that provide a perspective in analytically discussing my interlocutors' experience of moral epistemologies and ethical dispositions.

Responsibility, in their ontology, is not merely retrospective nor prospective, it is immediate, conjured the instant that the individual is in conscious awareness that there are others, and based on a theological underpinning. Ethical responsibility does not stem from any kind of direct accountability; it is the direct necessity for occupying a place in the world (Cloke 2002). In this context, I find it useful to discuss Levinas' use of illeity, to refer to God as a condition for responsibility. God is not a scriptural or dogmatic figure in this thinking, it is a condition higher than the self that links the $I$ in a responsible relationship with the other (Levinas 1969). God is mentioned as "the Third" in his work: "Levinas also begins to refer to "the Third" as an indirect relation to God [... ]. In the ethical relation, the trace of illeity left by the past presence of "the Third" is experienced. By way of the trace of illeity, the experienced in the face-to-face encounter with the other, "the Third" invests me with the responsibility for an other (Topolski 2015, p. 126).

According to Levinas, this responsibility towards the other (that is higher than the self) is a way of experiencing the transcendental through the human. He develops this thought by adding that "the relation to God is never outside of the relation to the other person" (Topolski 2015, p. 126). Levinas basis his ideas on Judaic thought; especially, his impressions of the Third is drawn on a monotheistic deity. Nevertheless, this incentive that the self-other-god triad is inextricably linked through responsibility is highly relevant to our case. Levinas' theory, as noteworthy as it is, is insufficient in providing us with a picture of what kind of responsibility this phenomena entails. He effectively refers to a responsibility toward the sanctity of life. Nevertheless, this still remains ambiguous.

While responsibility is a disposition beyond the self or the (human) other, it is a non-negotiable fact that its daily manifestation emerges as a reflection on these structures. In this paradigm, we cannot ignore the subject's personal devotion to the divine, nor their subject formation within a social-political context. Ultimately, I suggest that we do not get too lost in analyzing the power structures, but look at how these structures influence the lived interpretation of religious orthodoxies. As members of a religious community often perceived of as the 'other' it is significant to layer out how my interlocutors make sense of community as they deliberate on responsibility. What does it mean to be a community? What kind of responsibility does this project on them as members of such a community? I turn to Hannah Arendt, who in her close reading of (political) morality in times of crises, illustrates a framework through which the other is incorporated into the moral imaginary through conceptions of responsibility. In her article, Truth and Politics (1967), written for the New Yorker she states: 
Political thought is representative. I form an opinion by considering a given issue from different viewpoints, by making present to my mind the standpoints of those who are absent; that is, I represent them. This process of representation does not blindly adopt the actual views of those who stand somewhere else, and hence look upon the world from a different perspective; this is a question neither of empathy, as though I tried to be or to feel like somebody else, nor [ ... ] of joining a majority but of being and thinking in my own identity where actually I am not. (Arendt 1967, p. 9)

In this excerpt, Arendt conveys that the ' $\mathrm{I}$ ' has the duty of representing the other-in their absence and opinions should be made in consciousness of the other (who is always present in the mind). We can see how Arendt moves beyond the liberal duality, I-other, and suggests a more collective understanding of togetherness. She exceeds conceptions of responsibility which hold the individual accountable for their conduct only, arguing that they are also responsible as part of a collective for things that have not done (Arendt 1994). In her own words, Herzog clarifies this explanation: "An agent will be held responsible for his/her words and deeds only if s/he belongs to a public sphere at the moment of his/her acts: "The disclosure of the 'who' through speech, and the setting of a new beginning through action, always fall into an already existing web where their immediate consequences can be felt". Responsibility in acting is apparently determined, or at least preceded, by fellowship. I am responsible in acting because I share a collective responsibility with my fellow citizens. I am therefore responsible for my acts as they are determined by an existing group of people to whom I belong and for whose previous actions I am also responsible, and then I am responsible for beginning something radically new based upon my own initiative" (Herzog 2004, p. 43).

My interlocutors repeat full awareness of the internal dynamics of these structures as they act on them. Similar to Arendt's approach, their desire is not to fully reproduce these structures, nor to contradict them defiantly; it is to initiate a change acting within these dynamics. When Arendt observes that the responsibility of the agent in changing their public space (through their own actions), she does not mention that these actions are constructed within a system. This section provides an introductory brief on approaches to responsibility. It critiques modern thoughts of the individual as a rational agent, and thus responsibility as an employment that begins and ends with the individual.

I acknowledge the vitality of recognizing structural and discursive influences on how responsibility becomes a lived reality for the individual. Nevertheless, I argue that there is more depth to the matter, and if we are to understand volunteering truly as a way of life for the Muslim women, we need to understand how they experience and unpack responsibility. It implicates more than just personal accountability, and asks for a devotion on part of the individual; a devotion to community, which they trace back to merely existing. To be concerned of the other is their ultimate link to God, and asks for their awareness of being aware of suffering and the sanctity of mere existing. I draw on the work of Emmanuel Levinas, whose phenomenological reading of responsibility lays a theoretical foundation for analytically engaging with this experience. Levinas falls short of bringing clarity to what kind of responsibility this thinking introduces, for which I turn to Hannah Arendt. Her prescriptive account of responsibility provides a gap through which I can frame my interlocutor's communitarian concerns. In this regard, being matters. Moreover, being is doing. The individual can only be present if they act on their presence, and this mere action has to take every other member of the society into consideration. Being cannot be separated from belonging. It is only by acting on this belonging can they maintain the continuity of their self, their community, and the larger society.

\section{The Common Good, Unpacking Maslaha}

My interlocutors locate responsibility in the judicial category of maslaha. Maslaha is the judiciary term that refers to the protection of five values: Religion, life, progeny, property, and rationality. The term itself has been re-read throughout the ages and has been subject to interpretation especially with the socio-political shifts in the Islamic world in the 20th century. In the case of my interlocutors, maslaha is more than a judiciary term, and it's scope reaches far beyond the responsibility of the state, 
or the law enforcement. Maslaha is the common good that must be respected by everyone, and which must be ensured by everyone. Moreover, it is a civil code, a civil norm much like in the ways in which liberalism has civil norms and codes. It is exactly at this point where my interlocutors' conception of liberal responsibility and responsibility in the Islamic tradition merge in their lifeworlds. We will unpack how this is deliberated and practiced in the coming sections. However, I would first like to unpack what the common good means for the female volunteers.

Khaled Masud, who has written extensively on the concept of maslaha, describes it as a way of being good and manifesting all the good values such as "uncorrupted, right, honest, virtuous and just" (Masud [1977] 2000, p. 135). Furthermore, maslaha specifically means the "cause or source of something good or beneficial" (Opwis 2005, p. 182). Salvatore describes that it was thanks to the work of al-Shatibi that the maslaha became a concept that covers a "theory of social action and interaction" that is known to us as the "common good" (Salvatore 2007, pp. 156-71). We have already discussed maslaha as a judicial category-the protection of values. However, how is this term re-read in the context where the five values are already being protected by the liberal state?

My interlocutors are already aware that maslaha in the classical sense of the term is outdated in the modern context. It is without doubt that any kind of violation of the five values is more than a sin, but also a crime. In this context then it is up to them to re-think and re-signify what the common good is, although it may not become a judiciary category in the classical sense of the term. The common good is one of the fundamental principles that embed their social relationships and the ways in which they reflect on their public presence. I suggest that such an understanding of the common good where liberal norms are in direct conversation with Islamic concepts imply a certain way of subject formation. It implies a type of subject formation that leans on more than one moral ontology. This is subject position is conveyed as the one that is of the 'good Muslim' for my interlocutors. While this may seem in the boundaries of common sense, I argue that it is interesting to explore how these traditions come in a way that speak to public discourse. Ultimately, it indicates that subject formation and the reading of moral norms cannot be detached from how social and political discourses are framed especially in relation to minorities and especially Muslims.

The former head of the (Belgian) Royal Commission on Migration Policy, Paula D'hondt, in her 1989 policy report explained that migrants" "cultural expressions" should not "pose a threat to the public order nor to the social principles that the host country holds on to" (Zemni 2011, p. 31). Ismail adds that this is in relation to the image that Muslims are "recalcitrant subjects" (Ismail 2008, p. 25), and it is to this that I add that my interlocutors respond with the common good.

How do my respondents respond to assertions as that of Paula D'hondt? Negative stereotypes surrounding Muslims-especially Muslim women-is not uncommon. How does the common good enter the scene in such cases where Muslims are faced over again with the question of whether they can integrate into the liberal-secular scene, of whether they can emancipate their women, or whether they can be progressive etc.? My interlocutor, Ilknur, who was the secretary of one of the associations in Brussels at the time, explained this to me in our discussion: "Well a good Muslim is a good citizen," Ilknur said. "We do these things because we believe that a good Muslim should find solutions for problems in their community. That what we try to do here..."

By 'these things', she was referring to the variety of events they organized in their associations, and the issues they covered during those events. Ilknur explained to me how very well they were aware of the problems surrounding minorities, especially those living in the neighborhoods heavily populated by Turks or Moroccans. "A good Muslim is a good citizen" reflects how Ilknur has internalized an understanding that I hear a lot among my informants, and that is often reflected in how they choose to develop an event. One of these included the 'Tea with Multicultural Mothers' event. The concept consisted of mothers coming from different backgrounds living in the diversely populated Schaerbeek region of Brussels to come together and have tea together. The mothers would then share their experiences/problems of being different, being a minority and raising children. Indeed, they shared their stories over tea and cookies. There were women from very different backgrounds in the event; 
they are women from the Congo, Morocco, Turkey, and Iraq. Some were born and raised in Belgium some had just migrated but the stories generally consisted of similar experiences. They were mothers trying to raise their children as best as possible in a diverse environment, usually faced with cultural and religious challenges. They talked about negative attention, the hardships they faced keeping their children in school, and ultimately unemployment.

Eventually, I started seeing a pattern in themes of the events they organize, and bringing together mothers from different ethnic and cultural backgrounds that fit that pattern. My interlocutors do target social problems at their events, but I noticed that they target these social problems in a way that the problems are reflected on them. I find notable that during the time I carried out participant observation, I did not come across an event where they engaged with inequality, racism, or Islamophobia, which are some social problems that they also acknowledge to exist. Similar to the 'multicultural mothers' event, they usually reflect on issues like unemployment, educational problems, radicalization, and in general the problem of 'integration', or indeed the lack of it. When I asked my informants, quite like Ilknur, they told me that it is their duty as good Muslims to challenge these problems. The issues they choose to claim and address, and the themes they do not claim or address, indicate how their volunteering is informed by public discourses and re-articulated by reference to the Islamic tradition.

I do not mean to say that my interlocutors are oblivious of the negative discourses surrounding their Muslim presence in society. In our personal discussions, they often refer to how hard it is to be a Muslim woman and sustain a professional life. Tuba, who is now a doctor and graduated from her Masters degree with a summa cum laude, once told me that "whatever your grades, you can never be the most successful student in your class if you are a woman wearing a headscarf". She said that she often felt belittled and under-appreciated by her doctoral advisor, who never even wanted her in the first place; they were somehow "stuck together".

Tuba's mostly negative experiences as a visibly Muslim PhD student are shared among her close friend group. Esra, a very out-going volunteer and a close friend of Tuba's, told me how it was difficult for her to find a job as a veiled pharmacist because most of the pharmacies she applied to explicitly told her they did not want a visibly Muslim woman interacting with her customers. It was only when a woman of Moroccan background, who understood her religious sensitivities, hired her that she started working again. These stories are not new to me, and the research on their real difficulties is extensive (Göle 2003; Amir-Moazami 2001; Shadid and Van Koningsveld 2005; Maussen 2006).

However, such narratives do not seem to be incorporated into my informants' volunteering agenda. One can surely be a good citizen by effectively challenging structural and social inequality. Unpacking events such as the 'multicultural mothers' event is hence significant in this sense. It is an indication of how 'the good Muslim' is constructed in conversation with social and political narratives of minorities, Muslims, the idea of multiculturalism (or its failure), ideal citizenship, and of course, integration.

What interests me most, more than the different forms of xenophobia/Islamophobia my respondents experience in their daily life, is that these conflicts seem to arise the most when they are pursuing this desire of being a good Muslim and social participation. From what they convey to me, I understand that the ideal that is projected on my interlocutors is also where their challenges begin. It is at this point, I observe, where they see their calling takes shape, in the implicit but immanent cracks of a social imagination that cannot deal with the idea of accepting what, for them, is completely obvious and profound. This point was echoed by Elif when I asked her how they develop their events. "We need to show that Islam is not like they (the non-Muslim) think it is: backward and closed to development. Or Muslims are not like they see on the media." This statement takes us back to the assertion that "a good Muslim is a good citizen", suggesting that their religiosity is embedded in a context, or more explicitly how they describe a good citizen. 
My informants do not naturally absorb these narratives but critically engage with them, negotiating with them in respect to how they construct their piety. The events they develop and carry out cultivate the self that is the pious 'good citizen'. The emphasis on tackling educational problems is a clear indication of how they acknowledge the discourse on Turkish Belgian students' low educational progress. It is a discourse that is often described in statistical terms (Timmerman et al. 2003; Crul 2007). This was such a recurring issue that the years 2012-2013 were devoted mostly to challenging low-education, and later integration into the labor market, in the case of Turkish youth.

One of the biggest events the volunteers organized was the three-day symposium 'Diverse Talents for the Future of Europe'. Policy makers, academics, and NGO representatives were all invited to present their findings on the educational situation of youth with immigrant backgrounds and how the youth can be helped and eventually 'integrated' into the labor market. Of course, there were a wide array of ideas and numbers thrown at us, but the main one was that, for some reason, these youngsters were showing lower development than their 'white' peers and that this inevitably impacted their employment options in the future. After the symposium, a report was issued with the main bullet points. I asked Elif and some other informants, who were working in executive positions of the associations, why they felt the need to organize such an event, as it must also cost them a lot.

"Because we wanted to raise awareness of the problems surrounding the minority youth here," she said. "[We wanted to] do something about that, you know, work for a solution." Elif's initial assessment is that their events should tackle the "problems surrounding the minority", which is a consciously chosen framework as opposed to problems that are 'reflected' on the minority. Similar to the issue we discussed before about the headscarf, it is not that my informants do not experience the challenges of social and political narratives reflected on them as a religious minority, but that they choose to frame their engagement with them in a certain form. That form is to accept minority problems as minority problems and tackle them from within, instead of shifting their attention to stigmas and challenges inflicted on them as a community.

The associations, both in Brussels and in Antwerp, are structured so that they cover certain platforms: the youth platform, the women's platform, the platform for professionals and expats, etc. The different platforms focus on different projects that usually center around a focus group. However, even this structuring is telling, in the sense that they are insinuating their public presence within the charters of a discourse, the good Muslim. The good Muslim is an identity, which is taken up by the volunteers themselves and which they desire to become. However, the good Muslim's hermeneutics, registers, and vocabularies are shaped through social and political discourses that are ultimately projected as a mainstream expectation of them. The audience of the good Muslim is not just God, but the whole public.

This approach in their volunteering is not detached from the Islamic tradition. It is embedded in a religious narrative that they accept as authoritative. With my sohbet group, we listened to an Islamic scholar's lessons from a website, where they were posted on a weekly basis. A scholar in one particular lesson asserted that a Muslim must always serve their country. He added that "the love for one's country depends on iman (faith)". Patriotism is a common theme in Islam, and it is very prominent among my informants, who usually translated the lesson to mean "a good Muslim is a good citizen". Scholars acknowledge that religious traditions are "institutionally" and "discursively" grounded, which provide a "set of moral and social references", which then shape their social practices and the discourses that embed those practices (Amir-Moazami and Salvatore 2003, p. 5). In this light, my informants re-shape Islamic patriotism by problematizing the concept of 'country,' or more specifically, which country one is to serve as a Muslim living in a country like Belgium. They unpack the 'servable country' by reference to the nation-state discourse.

The volunteers' sense of responsibility is two-fold: The responsibilities they bear as being creations of God, and responsibilities they take upon themselves as being part of society. The first part is connected to how they interpret being a Muslim, the second is connected to how they interpret being a good Muslim. Levinas suggests responsibility to be something beyond the individual. It is a 
disposition where the subject is connected to the well-being of the other, without necessarily having to be in any mutual relationship with the other; the subject is responsible of those she/he may not even know. This is necessary for the continuation of life. For my interlocutors this is necessary for the establishment of common good and the protection of the five values. Thus, volunteering becomes a way of fulfilling this responsibility. This is a part of life that is essential; it cannot be delayed or transferred to someone else. However, the protection of values takes a different shape according to time and society. For the female volunteers it is essential to re-read their responsibilities in light of contextual necessities. These necessities are inextricably linked to the issues pertaining minorities, and especially Muslim minorities. Thus responsibility is a set of practices that protect the dignity and the right of being of the Muslim communities in a non-Muslim country. We have seen over and again how each event is carefully structured to speak to issues that take up significant space in public discourses. It is their responsibility to tackle these issues, thus the argument they make flipped; it is not discrimination, racism, or even Islamophobia that they deal with but the problems that may exist among themselves that cause these issues. This is a conscious choice; their responsibility addresses what they can do and what they change about themselves and not the larger society. Ultimately, they do believe that if they can tackle minority problems then the negative attention will also fade away. This may seem problematic, however it still offers a different and clearer way of thinking through how responsibility and social relationality is conceptualized by Muslim individuals. It offers us a way of thinking through how ideas of how responsibility re-signifies 'patriotism' and is offered a moral ground by adding God to the equation. In the next section I turn to how this chain of thought is problematized when it comes to Muslims who do not read responsibility in this line.

\section{The Good Muslim and the Not So Good Muslim}

Thus far, we have discussed a certain way of subject formation. We have discussed how this subject formation is imbricated in the idea of taking up responsibility as a duty that comes from God. The Muslim subject is responsible of others beyond any liberal account of responsibility. They are inextricably bound to society through God. This notion of responsibility is unpacked in dialogue with public discourses of responsibility. Furthermore, this signifies a very specific type of Muslim self. One that is non-liberal and in touch with the consciousness of God and that is also in touch with their current context. I suggest that this type of Muslim self is formed differently from other types of Muslim-ness that are perceived as unable to be in touch with their context and thus unable to understand the liberal side of responsibility; suggesting an irresponsibility on the side of the Muslim. This idea speaks in the paradigms of the 'good Muslim-bad Muslim' divide.

Here we see a discursive construction of two types of Muslims: One that can re-read their religion through the liberal requirements of their context, and the other who is unable to do so. The next question pertains to what kind of affects and behaviors constitute the 'bad Muslim'. During one of our weekly religious classes, the issue came to radicalism, or in the words of my interlocutors, extremism. Indeed, extremism would be the better word to use, because in their conception there is extremism and the extreme way in which religion is interpreted and lived which is completely detached from the context. Then there is radicalism, which is a violent expression, which causes hurt and damage and cannot be located in religion whatsoever.

Hence, we were to talk about extremism as our teacher told us that evening, "Today I will talk about zealotry, bigotry in religion and extremism. I mean it is at this point that we see the importance of ijtihad and open mindedness. If we want to live in this society, we have to let go of this reaction and embrace what we have." She said this to us and continued to talk about the necessity of working in the society with the society. She said this drawing of a thick bold line between the non-reactionary good Muslim and the reactionary bad Muslim. She was very much aware that not every reactionary Muslim is an extremist, however, they are very similar approaches in terms of framework. There is an emphasis in differences. Activist Muslims, who publicly carry out their political demands and 
who ask for an acceptance of their differences (see Fernando 2014) are categorically problematic for my interlocutors.

For my interlocutors the subject has "moral obligations" to the state and the society (Foucault 2003, p. 27). Foucault asserts that the person is subjectivated, by being subjected to relations of power through discourse, "This form of power applies itself to immediate everyday life which categories the individual, marks him by his own individuality, attaches him to his own identity, imposes a law of truth on him, which he must recognize and which others have to recognize in him. It is a form of power that makes individuals subjects. There are two meanings of the word subject: Subject to someone else by control and dependence, and tied to his own identity by a conscious self-knowledge. Both meanings suggest a form of power which subjugates and makes subject to" (Foucault 1982, p. 212).

He suggests that the subject is formed in the context of power relations, which assert a certain truth - a way of being — on the individual. That certain way of being is performed by the individual making them a subject. Taking off from Foucault's definition of subjectivation Judith butler adds, “'subjectivation' ... denotes both the becoming of the subject and the process of subjection-one inhabits the figure of autonomy only by becoming subjected to a power, a subjection which implies a radical dependency. [ . . . ] Subjection is, literally the making of a subject, the principle of regulation according to which a subject is formulated or produced. Such subjection is a kind of power that not only unilaterally acts on a given individual as a form of domination, but also activates or foms the subject. Hence, subjection is neither simply the domination of a subject nor its production, but designates a certain kind of restriction in production" (Butler 1997, pp. 83-84).

The stereotypes or the problems projected on Muslims by social institutions, the media, and of course by politicians become mechanisms of instigating a proper way of being. From this perspective my interlocutors are subjected into being good Muslims on basis of the public's reiteration of examples of bad Muslim-ness. In the case of the volunteers, the power relation between them and the majority is grounded in the fact that they are a minority who are expected to integrate into the majority culture. Thus those who cannot integrate into this culture are-by the standards of the majority-bad.

\section{Conclusions}

This article explores how responsibility takes shape in the daily experiences of female Muslim volunteers. I stress the issue of volunteering here because it is the exact space where both the discursive and practical dynamics of responsibility take shape. The volunteer's conception of responsibility is embedded in Islamic principles of the common good, and the liberal democratic understanding of goodness, and being a good citizen. It is apparent that there are many goods in this equation. Thus this article gradually moves on to the exclusionary nature of this goodness, wherein those who do not understand responsibility in such a way are ultimately not good.

The first step of the article is to sketch a very theoretical picture of responsibility; how does it diverge from the liberal and individual notion of responsibility, which begins and ends with the subject? It asks the questions: what does it mean to be responsible beyond the self, and beyond accountability? The section explores the work of Levinas, who detaches responsibility from the individual only partially in order to connect it with the notion of a higher being, a deity even. This resonates very well with my interlocutors, because for them, responsibility is a religious duty if anything. Responsibility is being responsible of every other creation in the world, only by also being a creation of God.

While this may seem very ambiguous and highly philosophical, it pertains to very real and grounded experiences for the volunteers. Their volunteering is a life-long endeavor and not a recreational activity. It is life-long because their responsibility of doing good is also life-long and far beyond their individual restrictions. Even in this framework responsibility has very tangible implications. It involves the society and the values of the society. While there is the judicial category of maslaha in Islam-the protection of the five values-for my interlocutors maslaha is open to re-interpretation. While life, property, progeny, and such values are protected by the state, 
their responsibility is to protect other aspects of life. These 'other aspects', not coincidentally, are also perceived as the individual's responsibility by the society. These can be personal empowerment, education, alleviating crime, and ultimately integration.

These are also some issues that are projected as problems or failures on the minority-especially Muslim-community. Thus, for the volunteers it is essential that volunteering addresses these issues. This also displays a very specific way of understanding problems and duties. My interlocutors prefer not to focus on structural inequality or stigma, since that is not their responsibility. They effectively own the issues linked to them. What we can observe here is an entanglement of non-liberal religious registers being in direct and constant conversation with (liberal) public dynamics.

The final section of the article discuss how this trajectory insinuates a certain type of subject formation - the good Muslim. Moreover, the good Muslim exists with its binary other: The bad Muslim. On the one hand my interlocutors embody such understanding of responsibility in order to be a better Muslim and citizen, on the other hand the Muslims who do not do so fail to understand their religion and their society. What we see here is a reflection on how public discourse creates a binary among Muslims. While this binary is a critical point of engagement, it should not go unnoticed that these differences are also re-articulated and re-created among Muslims themselves.

Conflicts of Interest: The author declares no conflict of interest.

\section{References}

Asad, Talal. 2009. Genealogies of Religion: Discipline and Reasons of Power in Christianity and Islam. Baltimore: JHU Press.

Abbas, Tahir, and Ismail Hakki Yigit. 2015. Scenes from Gezi Park: Localisation, Nationalism and Globalization in Turkey. City 19: 61-76. [CrossRef]

Amir-Moazami, Schirin, and Armando Salvatore. 2003. Gender, Generation, and the Reform of Tradition. From Muslim Majority Societies to Western Europe. Leiden: Muslim Networks and Transnational Communities in and across Europe, pp. 52-77.

Amir-Moazami, Schirin. 2001. Hybridity and anti-hybridity: The Islamic headscarf and its opponents in the French public sphere. Muslim Traditions and Modern Techniques of Power 3: 309-29.

Arendt, Hannah. 1967. Reflections: truth and politics. The New Yorker 43: 49-88.

Arendt, Hannah. 1994. Some Questions of Moral Philosophy. Social Research 61: 739-64.

Butler, Judith. 1997. Excitable Speech: A Politics of the Performative. London: Psychology Press.

Cesari, Jocelyne. 2004. When Islam and Democracy Meet: Muslims in Europe and in the United States. London: Palgrave Macmillan.

Cloke, Paul. 2002. Deliver us from evil? Prospects for living ethically and acting politically in human geography. Progress in Human Geography 26: 587-604. [CrossRef]

Crul, Maurice. 2007. The integration of immigrant youth. In Learning in the global Era: International Perspectives on Globalization and Education. Berkeley: University of California Press, pp. 213-31.

Deeb, Lara. 2006. An Enchanted Modern: Gender and Public Piety in Shi'i Lebanon. Princeton: Princeton University Press. Diprose, Rosalyn. 2008. Arendt and Nietzsche on responsibility and futurity. Philosophy E Social Criticism 34: $617-42$.

Etzioni, Amitai. 2011. Citizenship in a Communitarian Perspective. Ethnicities 11: 336-49. [CrossRef]

Fadil, Nadia. 2008. Submitting to God, Submitting to the Self. Secular and Religious Trajectories of Second Generation Maghrebi in Belgium. Ph.D. Dissertation, Catholic University of Leuven, Leuven, Belgium.

Fadil, Nadia. 2015. Rediscovering the "everyday" Muslim: Notes on an Anthropological Divide. HAU Journal of Ethnographic Theory 5: 59-88. [CrossRef]

Fernando, Mayanthi L. 2014. The Republic Unsettled: Muslim French and the Contradictions of Secularism. Durham: Duke University Press.

Foucault, Michel. 1982. The subject and power. Critical Inquiry 8: 777-95. [CrossRef]

Foucault, Michel. 2003. The Essential Foucault: Selections from Essential Works of Foucault, 1954-1984. New York: The New Press. 
Göle, Nilüfer. 2003. The voluntary adoption of Islamic stigma symbols. Social Research: An International Quarterly 70: 809-28.

Herzog, Annabel. 2004. Hannah Arendt's Concept of Responsibility. Studies in Social and Political Thought 10: 39-52.

Ismail, Salwa. 2008. Muslim public self-presentation: interrogating the liberal public sphere. PS: Political Science $\mathcal{E}$ Politics 41: 25-29.

Janoski, Thomas. 1998. Citizenship and Civil Society: A Framework of Rights and Obligations in Liberal, Traditional, and Social Democratic Regimes. Cambridge: Cambridge University Press.

Letiche, Hugo. 2006. Relationality and phenomenological organizational studies. Tamara Journal of Critical Organisation Inquiry 5: 7.

Levinas, Emmanuel. 1969. Totality and infinity: An Essay on Exteriority. Translated by Lingis A. Pittsburgh: Duquesne University Press.

Levinas, Emmanuel, Richard Kearney, and Richard A. Cohen. 1986. Face to Face with Levinas. Edited by Richard A. Cohen. Albany: State University of New York Press.

Lindley, Richard. 1986. Autonomy. Atlantic Highlands: Humanities International Press Inc.

Masud, Muhammad Khalid, ed. 2000. Travellers in Faith: Studies of the Tablīghì Jamā'at as a Transnational Islamic Movement for Faith Renewal. Leiden: Brill, vol. 69. First published 1977.

Maussen, Marcel. 2006. The Governance of Islam in Western Europe: A State of the art Report. Amsterdam: IMES, Institute for Migration and Ethnic Studies, University of Amsterdam.

Milan, Francesco F. 2016. Turkey: What Hides Behind a Fail Coup Attempt. The RUSI Journal 161: 28-32. [CrossRef]

Opwis, Felicitas. 2005. Maslaha in Contemporary Islamic Legal Theory. Islamic Law and Society 12: 182-223. [CrossRef]

Salvatore, Armando. 1997. Islam and the Political Discourse of Modernity. Reading: Ithaca Press (GB), vol. 4.

Salvatore, Armando. 2007. The Public Sphere: Liberal Modernity, Catholicism, Islam. Berlin and Heidelberg: Springer. Schielke, Samuli. 2007. Hegemonic Encounters: Criticism of Saints-Day Festivals and the Formation of Modern Islam in Late 19th and Early 20th-Century Egypt. Die Welt des Islams 47: 319-55. [CrossRef]

Shadid, Wasif, and P. Sjoerd Van Koningsveld. 2005. Muslim dress in Europe: Debates on the headscarf. Journal of Islamic Studies 16: 35-61. [CrossRef]

Schneewind, Jerome B. 1998. The Invention of Autonomy: A History of Modern Moral Philosophy. Cambridge: Cambridge University Press.

Timmerman, Christiane, Els Vanderwaeren, and Maurice Crul. 2003. The second generation in Belgium. International Migration Review 37: 1065-90. [CrossRef]

Topolski, Anya. 2015. Arendt, Levinas and a Politics of Relationality. London: Rowman \& Littlefield International. Venn, Couze. 2000. Occidentalism: Modernity and Subjectivity. Thousand Oaks: Sage.

Zemni, Sami. 2011. The shaping of Islam and Islamophobia in Belgium. Race E Class 53: 28-44. 